\title{
Pengaruh Penyuluhan Terhadap Tingkat Pengetahuan Kesehatan Reproduksi Pada Remaja SMP N 1 Madapangga Tahun 2018
}

\author{
Arif Budiwibowo', Junaidi ${ }^{2}$, Supriadin ${ }^{\mathbf{3}}$ \\ ${ }^{1), 2)}$ STIKES YAHYA BIMA \\ Email : arif.budiwibowo@yahoo.co.id
}

\begin{abstract}
ABSTRAK : Pengetahuan tentang kesehatan reproduksi sangat diperlukan oleh remaja sejak memasuki masa pubertas. Akan tetapi, pendidikan kesehatan reproduksi di Indonesia masih jarang dilaksanakan. Perlu ada pendidikan untuk mencegah terjadinya masalah terkait kesehatan reproduksi, salah satunya melalui penyuluhan. Tujuan dari penelitian ini adalah mengetahui pengaruh penyuluhan terhadap tingkat pengetahuan kesehatan reproduksi pada remaja siswa SMP N 1 Madapangga. Metode Penelitian ini menggunakan rancangan quasi-experimental one group pretest-posttest design. Sebanyak 33 sampel diambil secara cluster sampling dari siswa kelas II. Subyek diberi kuesioner pretest dilanjutkan dengan penyuluhan, dan diberi kuesioner posttest satu minggu setelahnya. Analisis data dilakukan dengan menggunakan paired t test dan alternatifnya yaitu uji Wilcoxon. Hasil Terdapat perbedaan tingkat pengetahuan yang bermakna setelah dilakukan penyuluhan $(\mathrm{p}<0,01)$. Perbedaan tingkat pengetahuan yang bermakna ada pada topik anatomi dan fisiologi kesehatan reproduksi, cara memelihara kesehatan organ reproduksi, serta penyakit menular seksual (PMS) dan HIV/AIDS dengan nilai p masing-masing 0,028; 0,022; dan 0,013 secara berurutan. Kesimpulan Penyuluhan berpengaruh terhadap tingkat pengetahuan kesehatan reproduksi remaja siswa SMP N 1 Madapangga. Terdapat peningkatan pengetahuan pada topik anatomi dan fisiologi organ reproduksi, cara memelihara kesehatan reproduksi, serta penyakit menular seksual (PMS) dan HIV/AIDS.
\end{abstract}

Kata kunci : penyuluhan, tingkat pengetahuan, kesehatan reproduksi, remaja

\section{PENDAHULUAN}

Kesehatan reproduksi, sama halnya dengan kesehatan pada umumnya, adalah hak setiap manusia. Untuk mampu mencapainya, diperlukan pengetahuan tentang kesehatan reproduksi yang benar dan komprehensif. Pengetahuan tersebut didapatkan melalui berbagai sarana, salah satunya adalah pendidikan. Pendidikan merupakan cara yang paling penting dan efePenelitianf untuk memperoleh pengetahuan tentang kesehatan reproduksi.

Pengetahuan tentang kesehatan reproduksi sangat diperlukan oleh masyarakat, khususnya penduduk remaja. Survei World Health Organization (WHO) tahun 2010, kelompok usia remaja (10-19 tahun) menempati seperlima jumlah penduduk dunia, dan $83 \%$ di antaranya hidup di negara-negara berkembang. Usia remaja merupakan usia yang paling rawan mengalami masalah kesehatan reproduksi seperti kehamilan usia dini, aborsi yang tidak aman, infeksi menular seksual (IMS) termasuk Human Immunodeficiency Virus (HIV), pelecehan seksual dan perkosaan. Dengan adanya pendidikan, diharapkan masalah-masalah tersebut dapat dicegah.

Di Indonesia, pendidikan kesehatan reproduksi belum banyak dilakukan. Pendidikan kesehatan reproduksi tidak tercakup di dalam kurikulum sekolah seperti yang direkomendasikan oleh WHO, karena adanya konflik antara nilai tradisi Indonesia dengan globalisasi kebarat-baratan yang dianggap muncul seiring adanya pendidikan kesehatan reproduksi. Di sisi lain, kasus-kasus yang berhubungan dengan kesehatan reproduksi di Indonesia masih tinggi. Sebagai contoh, angka remaja wanita usia 15-19 tahun yang melahirkan pada tahun 2010- 2015 mencapai 72 per 1000 orang. Data dari Kementerian Kesehatan RI menyatakan bahwa sejak April hingga Juni 2016, jumlah kasus Acquired Immune Deficiency Syndrome (AIDS) baru yang dilaporkan adalah 2.001 kasus dari 59 kabupaten/kota di 19 propinsi.

Hal-hal tersebut di atas menunjukkan pentingnya pendidikan untuk mencegah terjadinya masalah kesehatan reproduksi. Ada pun pendidikan kesehatan reproduksi di Indonesia umumnya dilakukan dalam bentuk penyuluhan oleh lembaga-lembaga di luar sekolah, seperti BKKBN dan PKBI. Penyuluhan lebih banyak dilaksanakan di tingkat Sekolah Menengah Atas (SMA) daripada Sekolah Menengah Pertama (SMP), padahal angka partisipasi pelajar SMP di Indonesia lebih tinggi daripada angka partisipasi SMA. Penelitian menunjukkan bahwa remaja di negara-negara berkembang sangat membutuhkan pendidikan kesehatan reproduksi. Remaja yang berada di tingkat awal sekolah menengah mempunyai risiko melakukan hubungan seksual di luar nikah baik disengaja maupun tidak. Oleh karena itu, masa yang paling tepat untuk memberikan pendidikan kesehatan reproduksi adalah pada tingkat akhir sekolah dasar. Hal ini juga akan menolong remaja yang tidak dapat melanjutkan studinya ke sekolah menengah. Selain itu, WHO menekankan pentingnya pendidikan kesehatan reproduksi kepada remaja muda (younger adolescents), yaitu kelompok usia 10 hingga 14 tahun. Usia ini merupakan masa emas untuk terbentuknya landasan yang kuat tentang kesehatan reproduksi, sehingga dapat mempersiapkan mereka untuk mengambil keputusan seksual yang lebih aman dan bijaksana dalam hidupnya. 
Berdasarkan hal-hal tersebut di atas, penelitian dilakukan untuk mengetahui pengaruh pendidikan, dalam hal ini dengan melakukan penyuluhan, terhadap tingkat pengetahuan kesehatan reproduksi siswa-siswi Sekolah Menengah Pertama (SMP), yang termasuk dalam kelompok usia remaja muda. Penelitian ini diharapkan dapat digunakan sebagai dasar pengembangan pendidikan kesehatan reproduksi dengan cara penyuluhan kepada remaja untuk mengatasi tingginya masalah kesehatan reproduksi di Indonesia.

\section{METODE PENELITIAN}

Penelitian ini menggunakan rancangan quasiexperimental one group pretest-posttest design. Populasi terjangkau adalah siswa kelas II Sekolah Menengah Pertama (SMP) N 1 Madapangga Kabupaten Bima. Penelitian ini menggunakan rancangan quasiexperimental one group pretest-posttest design. Sebanyak 33 sampel diambil secara cluster sampling dari siswa kelas II. Subyek diberi kuesioner pretest dilanjutkan dengan penyuluhan, dan diberi kuesioner posttest satu minggu setelahnya. Analisis data dilakukan dengan menggunakan paired $t$ test dan alternatifnya yaitu uji Wilcoxon

\section{HASIL DAN PEMBAHASAN}

1) Karakteristik Sampel

Dari data karakteristik sampel, didapatkan bahwa umur sampel terbanyak adalah 14 tahun $(48,5 \%)$ dan peserta perempuan lebih banyak daripada laki-laki (18 orang, 54,5\%).

Seluruh responden penelitian belum pernah mendapatkan penyuluhan tentang kesehatan reproduksi sebelumnya (100\%), sehingga tidak ada yang masuk dalam kriteria eksklusi. Sebagian responden pernah mendapatkan informasi tentang kesehatan reproduksi dari kelompok sebayanya, yaitu sebanyak 22 responden $(66,7 \%)$. Paparan informasi sebelumnya tentang kesehatan reproduksi berasal dari media massa dan internet atau dari konseling dengan guru. Sejumlah 12 sampel berada dalam kategori kurang, atau tidak pernah mendapat informasi sebelumnya $(36,4 \%), 14$ sampel berada dalam kategori sedang yaitu pernah mendapat informasi dari media massa/internet saja atau dari konseling dengan guru saja $(42,4 \%)$, dan 7 sampel pada kategori baik, yang pernah memperoleh informasi baik dari media massa, internet, maupun konseling dengan guru $(21,2 \%)$.

2) Analisis data hasil penelitian

a) Analisis tingkat pengetahuan sebelum dan sesudah penyuluhan

Pada analisis ini, seluruh sampel diikutsertakan dengan menghitung jawaban yang dikosongkan sebagai jawaban salah. Dari uji normalitas data dengan menggunakan metode Shapiro-Wilk, didapatkan $p>0,05$ baik pada data pretest maupun posttest, sehingga dapat disimpulkan bahwa kedua data memiliki distribusi yang normal.

b) Analisis pengetahuan per topik kesehatan reproduksi

Dalam penelitian ini juga dilakukan analisis peningkatan pengetahuan pada setiap topik. Topik yang terdapat pada penelitian ini adalah anatomi dan fisiologi organ reproduksi, cara memelihara kesehatan organ reproduksi, pubertas, kehamilan dan aborsi, serta penyakit menular seksual (PMS) dan HIV/AIDS. Sampel yang diikutsertakan dalam analisis data ini adalah sampel yang menjawab setiap topik dengan lengkap tanpa ada yang dikosongkan.

Pada data hasil pengetahuan per topik ini dilakukan uji normalitas data pada setiap topik, dan hasilnya distribusi pada semua data tidak normal $(p>0,05)$. Selanjutnya dilakukan usaha transformasi data, namun data tetap tidak normal, sehingga untuk analisis data digunakan uji non parametrik Wilcoxon.

Dari uji di atas didapatkan bahwa angka kemaknaan untuk topik anatomi dan fisiologi organ reproduksi, cara memelihara kesehatan organ reproduksi, pubertas, kehamilan dan aborsi, serta penyakit menular seksual (PMS) dan HIV/AIDS (p) masing-masing adalah 0,028; 0,$022 ; 0,160 ; 0,079$; dan 0,013 secara berurutan. Hal ini menunjukkan bahwa terdapat peningkatan pengetahuan yang signifikan pada pengetahuan tentang anatomi dan fisiologi kesehatan reproduksi, cara memelihara kesehatan organ reproduksi, serta penyakit menular seksual (PMS) dan HIV/AIDS $(\mathrm{p}<0,05)$. Sedangkan pada topik pubertas serta kehamilan dan aborsi, tidak ada peningkatan pengetahuan yang signifikan $(p>0,05)$.

c) Analisis variabel perancu

Dalam penelitian ini terdapat dua variabel perancu, yaitu paparan informasi dan lingkungan pergaulan atau kelompok sebaya. Untuk mengukur variabel perancu, digunakan data selisih nilai yang dianggap bermakna, yaitu peningkatan skor pretest - posttest sebesar minimal $10 \%$.

Pada data paparan informasi dan lingkungan pergaulan atau kelompok sebaya, dilakukan uji normalitas dan didapatkan bahwa sebaran data tidak normal $(\mathrm{p}<0,005)$. Kemudian dilakukan usaha transformasi data, tetapi setelah transformasi, data yang dihasilkan tetap tidak normal, sehingga untuk analisis variabel perancu tersebut digunakan uji non parametrik. Pada variabel paparan informasi digunakan uji Kruskal-Wallis, sedangkan pada variabel lingkungan pergaulan atau kelompok sebaya digunakan uji Mann-Whitney. Hasil uji KruskalWallis untuk paparan informasi adalah $\mathrm{p}=0,751$ 
sehingga dapat dinyatakan bahwa paparan informasi sebelumnya tidak berpengaruh terhadap peningkatan pengetahuan $(p>0,005)$ Hasil uji Mann-Whitney untuk lingkungan pergaulan atau kelompok sebaya adalah $\mathrm{p}=0,304$ sehingga dapat dinyatakan bahwa lingkungan pergaulan atau kelompok sebaya tidak berpengaruh terhadap peningkatan pengetahuan $(\mathrm{p}>0,005)$.

\section{3) Pembahasan}

Hasil analisis data tentang tingkat pengetahuan menunjukkan bahwa subyek telah memiliki pengetahuan pada pretest. Kurang lebih 59\% dari subyek memperoleh nilai lebih dari rata-rata. Pada posttest didapatkan kurang lebih $70 \%$ dari subyek memperoleh nilai lebih dari rata-rata. Dengan demikian, hipotesis yang menyatakan bahwa penyuluhan berpengaruh terhadap tingkat pengetahuan kesehatan reproduksi pada remaja siswa SMP N 1 Madapangga dapat diterima. Hal ini sejalan dengan penelitian yang sejenis di SMP Eka Sakti di mana terdapat peningkatan pengetahuan setelah diberikan penyuluhan tentang bahaya HIV dan AIDS serta penelitian di Surakarta yang menyatakan terdapat pengaruh pemberian penyuluhan yang signifikan terhadap pengetahuan remaja perempuan SMP Muhammadiyah.

Dapat dinyatakan bahwa penyuluhan memiliki pengaruh yang signifikan terhadap tingkat pengetahuan remaja siswa SMP N 1 Madapangga. Dalam hal ini, penyuluhan yang dilakukan berupa ceramah dengan alat bantu audio visual serta pelaksanaan umpan balik atau feedback berupa permainan singkat. Dalam aplikasinya, kegiatan penyuluhan ini dapat dimanfaatkan untuk menunjang kegiatan belajar-mengajar di sekolah, dan bahkan dapat dikembangkan sehingga menjadi bagian dari kurikulum di sekolah menengah pertama. Hal ini dapat diwujudkan apabila ada kerja sama antara Kementerian Pendidikan Nasional, Kementerian Kesehatan, serta pihak-pihak terkait lainnya.

\section{KESIMPULAN}

1. Penyuluhan berpengaruh terhadap tingkat pengetahuan kesehatan reproduksi remaja siswa SMP N 1 Madapangga.

2. Terdapat peningkatan pengetahuan pada topik anatomi dan fisiologi organ reproduksi, cara memelihara kesehatan organ reproduksi, serta penyakit menular seksual (PMS) dan HIV/AIDS.

\section{DAFTAR PUSTAKA}

[1] Departemen Kesehatan Republik Indonesia. Modul pelatihan bimbingan dan penyuluhan kesehatan reproduksi remaja bagi petugas kesehatan: pegangan bagi pelatih. Jakarta: Depkes RI; 2000.
[2] Dahlan MS. Besar sampel dan cara pengambilan sampel dalam penelitian kedokteran dan kesehatan. Jakarta: Salemba Medika; 2010.

[3] Kementerian Kesehatan Republik Indonesia. Profil Kesehatan Indonesia 2009. Jakarta: Kementerian Kesehatan R.I.; 2010

[4] Notoatmodjo S. Pendidikan dan perilaku kesehatan. Jakarta: PT Rineka Cipta; 2003.

[5] Tim Penulis Poltekkes Depkes Jakarta I. Kesehatan remaja: problem dan solusinya. Jakarta: Salemba Medika; 2010.

[6] Kusmiran E. Kesehatan reproduksi remaja dan wanita. Jakarta: Salemba Medika; 2011.

[7] Wiknjosastro H. Ilmu kebidanan. Jakarta: Yayasan Bina Pustaka Sarwono Prawirodihardjo; 2007.

[8] Hasmi E. Membantu remaja memahami dirinya: bacaan bagi fasilitator. Jakarta: BKKBN; 2002. 